This is a pre-copyedited, author-produced PDF of an article accepted for publication in IMA Journal of Management Mathematics following peer review. The version of record Asgari, Nasrin, Nikbakhsh, Eshan, Hill, Alex and Zanjirani Farahani, Reza (2016) Supply chain management 1982-2015 : a review. IMA Journal of Management Mathematics, is available online at: http://dx.doi.org/10.1093/imaman/dpw004 . 


\title{
Supply Chain Management 1982-2015: a review
}

\begin{abstract}
Organizations need to better design, manage, and improve their supply chains as these become global and more complex. To do this, they need to learn from other organizations and sectors, preempt problems before they occur, and understand the future challenges they may face. Although over 40,000 articles and books have been published on supply chain management since coining the term in 1982, a clear understanding of the emerging trends, current knowledge gaps, and potential areas for future development does not exist. Our bibliometric analysis of the existing literature suggests we still need to better understand how to manage security, insourcing, sustainability, competition, risk and disruption, and human behaviour within supply chains. Equally, there is still a lack of research within healthcare, disaster and humanitarian supply chains, as well as within small and medium enterprises.
\end{abstract}

Keywords: supply chain management; research; surveys; bibliometrics.

\section{Introduction}

The term 'supply chain' (SC) was first coined in 1982 by Oliver and Webber, two professional consultants, who described it as a "network of organizations that are involved, through upstream and downstream linkages, in the different processes and activities that produce value in the form of products and services in the hands of the ultimate consumer" (Christopher, 2005; Stadtler and Kilger, 2011). Since then, many researchers have tried to understand and explain how organizations should integrate activities across their chain and coordinate the flow of material, information and money to better support market needs and improve the overall competitiveness of the chain (Stadtler and Kilger, 2011; Hill and Hill, 2012). However, a clear understanding of the emerging trends, gaps within our existing knowledge and potential future developments does not exist.

Previous supply chain management (SCM) literature reviews and surveys (see Table 1 for a selection) tend to look at just one aspect of SCM (such as information sharing, inventory management, network design, or SC integration) and a narrow range of academic journals. As a result, some topics and industries have not been explored even though they become more relevant as different business environments, practices, and challenges emerge. Creating a unified overview of SCM trends, gaps and future developments is a worthwhile, but challenging task as the SCM 
literature comprises over 40,000 journal articles and books on a diverse range of topics with a vast number of research methodologies. Therefore, this paper looks at all the SCM books and journal articles published over 1982-2015 to identify a set of guidelines for SCM academics and professionals to help them focus their research and practice on the most significant issues and areas in the future.

Table 1. A selection of supply chain literature reviews and surveys (1997-2015)

\begin{tabular}{|c|c|}
\hline Subject(s) & Reference(s) \\
\hline \multirow[t]{4}{*}{ Global supply chain } & Vidai and Goetschalckx (1997) \\
\hline & Meixell and Gargeya (2005) \\
\hline & Hammami et al. (2008) \\
\hline & Zeng et al. (2012) \\
\hline \multirow[t]{3}{*}{ Supply chain management in different countries } & Pyke et al. (2000) \\
\hline & Lorentz and Hilmolla (2008) \\
\hline & Tyagi and Agarwal (2014) \\
\hline \multirow[t]{3}{*}{ E-supply chain management } & Johnson and Whang (2002) \\
\hline & Zou and Seo (2006) \\
\hline & Alvarez-Rodríguez et al. (2014) \\
\hline \multirow[t]{7}{*}{ RFID and supply chains } & Coyle (2003) \\
\hline & Garfinkel et al. (2005) \\
\hline & Juels (2006) \\
\hline & Mehrjerdi (2008) \\
\hline & Kumar et al. (2009) \\
\hline & Sarac et al. (2010) \\
\hline & Peppa et al. (2013) \\
\hline \multirow[t]{2}{*}{ Information sharing in supply chain } & Huang et al. (2003) \\
\hline & Zhonghua and Ling (2013) \\
\hline \multirow[t]{3}{*}{ Third party logistics } & Selviaridis and Spring (2007) \\
\hline & Marasco (2008) \\
\hline & Aguezzoul (2014) \\
\hline \multirow[t]{3}{*}{ Vendor managed inventory } & Tyan and Wee (2003) \\
\hline & Marquès et al. (2010) \\
\hline & Govindan (2013) \\
\hline \multirow[t]{7}{*}{ Supply chain integration } & Nurmilaakso and Kotinurmi (2004) \\
\hline & Power (2005) \\
\hline & van der Vaart and Dong (2008) \\
\hline & Chen (2010) \\
\hline & Melnyk et al. (2014) \\
\hline & Tyagi and Agarwal (2014) \\
\hline & Cao et al. (2015) \\
\hline \multirow{5}{*}{$\begin{array}{l}\text { Production planning and scheduling in supply } \\
\text { chain }\end{array}$} & Kreipl and Pinedo (2004) \\
\hline & Sahin et al. (2013) \\
\hline & Pahl and Voß (2014) \\
\hline & Panahifar et al. (2015) \\
\hline & Pereira and Costa (2015) \\
\hline Simulation in supply chain & Terzi and Cavalieri (2004) \\
\hline \multirow[t]{3}{*}{ Supply chain networks } & Mills et al. (2004) \\
\hline & Melo et al. (2009) \\
\hline & Eskandarpour et al. (2015) \\
\hline \multirow[t]{2}{*}{ Supply chain architecture } & Walker (2005) \\
\hline & Melnyk et al. (2014) \\
\hline \multirow[t]{5}{*}{ Supply chain management in different industries } & Miles and Breen (2005) \\
\hline & Mondragon et al. (2006) \\
\hline & Ahumada and Villalobos (2009) \\
\hline & González-Benitoa et al. (2013) \\
\hline & Denham et al. (2015) \\
\hline
\end{tabular}




\begin{tabular}{|c|c|}
\hline Subject(s) & Reference(s) \\
\hline & Sel and Bilgen (2015) \\
\hline Customer satisfaction in supply chain & Kocakoc and Sen (2006) \\
\hline \multirow[t]{11}{*}{ General review on supply chain management } & Croom et al. (2000) \\
\hline & Rungtusanatham et al. (2003) \\
\hline & Sachan and Datta (2005) \\
\hline & Kouvelis et al. (2006) \\
\hline & Gupta et al. (2006) \\
\hline & Burgess et al. (2006) \\
\hline & Storey et al. (2006) \\
\hline & Giunipero et al. (2006) \\
\hline & Alfalla-Luque and Medina-López (2009) \\
\hline & Daugherty (2011) \\
\hline & Seuring and Gold (2012) \\
\hline Supply chain communication systems & Cutting-Decelle et al. (2006) \\
\hline \multirow[t]{7}{*}{ Supply chain performance } & Huan et al. (2004) \\
\hline & Chan et al. (2006) \\
\hline & Shepherd and Günter (2006) \\
\hline & Gunasekaran and Kobu (2007) \\
\hline & Wong and Wong (2008) \\
\hline & Akyuz and Erkan (2010) \\
\hline & Ntabe et al. (2015) \\
\hline \multirow[t]{2}{*}{ Supply chain dynamics } & Geary et al. (2006) \\
\hline & Fayezi et al. (2012) \\
\hline \multirow[t]{5}{*}{ Flexibility in supply chains } & Stevenson and Spring (2007) \\
\hline & More and Babu (2009) \\
\hline & Fatemi (2010) \\
\hline & Seebacher and Winkler (2013) \\
\hline & Esmaeilikia et al. (2014) \\
\hline \multirow[t]{19}{*}{ Sustainable supply chain management } & Fleischmann et al. (1997) \\
\hline & Browne et al. (2005) \\
\hline & Meade et al. (2007) \\
\hline & Srivastava $(2007)$ \\
\hline & Carter and Rogers (2008) \\
\hline & Seuring and Müller (2008) \\
\hline & Bekkering (2010) \\
\hline & Ilgin and Gupta (2010) \\
\hline & Carter and Easton (2011) \\
\hline & Sarkis et al. (2011) \\
\hline & Gimenez and Tachizawa (2012) \\
\hline & Abbasi and Nilsson (2012) \\
\hline & Ashby et al. (2012) \\
\hline & Morgan and Gagnon (2013) \\
\hline & Lin et al. (2014) \\
\hline & Stindt ans Sahamie (2014) \\
\hline & Eskandarpour et al. (2015) \\
\hline & Fahiminia et al. (2015) \\
\hline & Ntabe et al. (2015) \\
\hline Humanitarian/disaster logistics & Apte (2009) \\
\hline \multirow{2}{*}{$\begin{array}{l}\text { Supply chain management technology } \\
\text { (Information/Logistics/Operations) }\end{array}$} & Boone et al. (2007) \\
\hline & Jede and Teuteberg (2015) \\
\hline Supply chain optimization & Hassini (2008) \\
\hline Supply chain in crisis & Tang (2006) \\
\hline Supply chain security & Khan and Burnes (2007) \\
\hline \multirow[t]{6}{*}{ Supply chain risk/uncertainty } & Williams et al. (2008) \\
\hline & Rao and Goldsby (2009) \\
\hline & Natarajarathinam et al. (2009) \\
\hline & Hintsa et al. (2009) \\
\hline & Olson and $\mathrm{Wu}(2010)$ \\
\hline & Tang and Musa (2011) \\
\hline
\end{tabular}




\begin{tabular}{ll}
\hline \multicolumn{1}{c}{ Subject(s) } & \multicolumn{1}{c}{ Reference(s) } \\
\hline & Colicchia and Strozzi (2012) \\
& Simangunsong et al. $(2012)$ \\
& Sodhi et al. $(2012)$ \\
\hline Soft computing in supply chain management & Ho et al. $(2015)$ \\
Complexity of supply chain & Kot al. (2010) \\
\hline
\end{tabular}

The first section of the paper describes the methodology and scope of the research. Trends in the content of the SCM over the last thirty years are then analysed by looking at the content of SCM textbooks published, the topics covered within peer-reviewed academic journals, popular quantitative tools and management techniques used in SCM studies, and types of industries that have been investigated. Gaps within the literature and research to date are identified to help propose future trends and identify future research directions. Finally, the conclusions and limitations of the research are discussed.

\section{Research Methodology and Scope}

In this study, we use bibliometrics as the foundation of our research methodology. In this method, quantitative and statistical measures are used to analyze the literature and create a better systematic understanding of literature (OECD, 2002). This method has already been applied for quantitative literature reviews of the SCM areas (e.g., see González-Benito et al. (2013) for a review of SCM in automotive industry and see Fahiminia et al. (2015) for a review of green SCM). Consequently, this study would differ from similar studies, because our study aims to create a comprehensive overview of the whole SCM field using quantitative data, while previous study usually pertains to only a specific area within SCM.

In this study, online databases were used to identify textbooks and journal papers with the keyword 'SCM' or 'supply chain' or 'supply chains' in their title, abstract or keywords. We found that Google Scholar and the Web of Science (ISI database) had the most comprehensive sources of citations with the Web of Science focusing on a selected number of journals and conference proceedings whilst Google Scholar includes a wider range of journals, books, conference proceedings, theses, dissertations, technical reports, handbooks and library guides (Mingersm 2009). However, SCOPUS offered greater flexibility when searching for specific words or phrases within document abstracts and keywords. Therefore, all three databases were used in our research, which is consistent with other studies such as Saad (2006) and Meho and Yang (2007).

Table 2 shows the types of documents that we identified. Given the objectives of this paper, we chose to focus on peer-reviewed journal articles (54.95\% of the documents) and books $(0.41 \%$ of the documents) published between 1982 and 2015 (relevant data retrieved on January 25, 2016). As 
such, it ignores other publications such as conference papers and technical reports and books. It also focuses on articles and books published in English, which represents $94.5 \%$ of the documents published to date.

\section{SCM Textbooks}

Textbooks are a good starting point for academics or practitioners wishing to learn about SCM whilst journal articles tend to be more useful for those wishing to research or apply a particular technique within a certain context.

Table 2. Type of SCM documents published as a percent of total (1982-2015)

\begin{tabular}{lrr}
\hline Document Type & \# Papers & \multicolumn{1}{c}{$\%$} \\
\hline Article & 37920 & 54.95 \\
Conference Paper & 22474 & 32.57 \\
Review & 3408 & 4.94 \\
Book Chapter & 1806 & 2.62 \\
Short Survey & 917 & 1.33 \\
Note & 855 & 1.24 \\
Conference Review & 743 & 1.08 \\
Editorial & 362 & 0.52 \\
Book & 283 & 0.41 \\
Business Article & 85 & 0.12 \\
Erratum & 59 & 0.09 \\
Letter & 28 & 0.04 \\
Abstract Report & 9 & 0.01 \\
Report & 6 & 0.01 \\
Undefined & 54 & 0.08 \\
\hline
\end{tabular}

\subsection{Popular textbooks}

Google Scholar (scholar.google.com) is the only one of our three databases that includes textbooks. A search on January 25, 2016 identified a list of top 10 most-cited SCM textbooks via Google Scholar as shown in Table 3. It should be noted that these figures are the total number of citations for all the editions of a book if that book had more than one edition.

Next leading SCM textbook publishers were also contacted (including Pearson and Cengage) to help identify which textbooks seem to be having an impact both in terms of sales and lecturer adoption as the core text for their modules. The four identified textbooks are Lysons and Farrington (2006), van Weele (2010), Christopher (2011), and Monczka et al. (2015).

\subsection{Content of popular textbooks}

Table 4 compares the content of the popular SCM textbooks identified in Section 3.1. This table shows that classical topics such as SCM strategies, performance measurement, network design, 
inventory management, procurement and purchasing, supply and demand planning, supplier relationship management, global SCM, and product design are covered in most textbooks. However, some advanced and relatively newer topics such as SC risk management, sustainability, and pricing and revenue management are treated less frequently. In addition, some important topics such as competition and applications of SCM in non-commercial environments (such as humanitarian and military logistics) are not covered in any of the popular textbooks.

Table 3. Top 10 most cited SCM textbooks

\begin{tabular}{|c|c|c|c|}
\hline Author(s) & Title & $\begin{array}{l}\text { Year } \\
\text { Published }\end{array}$ & \# Citations \\
\hline Chopra and Meindl & $\begin{array}{l}\text { Supply Chain Management: Strategy, Planning \& } \\
\text { Operation }\end{array}$ & 2012 & 5498 \\
\hline M. Christopher & $\begin{array}{l}\text { Logistics and Supply Chain Management: Strategies } \\
\text { for Reducing Costs and Improving Services }\end{array}$ & 1992 & 5013 \\
\hline $\begin{array}{l}\text { Simchi-Levi, Kaminsky, } \\
\text { and Simchi-Levi }\end{array}$ & $\begin{array}{l}\text { Designing and Managing the Supply Chain: Concepts, } \\
\text { Strategies, and Case Studies ( } 3^{\text {rd }} \text { ed.) }\end{array}$ & 2008 & 4449 \\
\hline Handfield and Nichols & Introduction to Supply Chain Management & 1999 & 2175 \\
\hline Christopher & $\begin{array}{l}\text { Logistics and Supply Chain Management: Creating } \\
\text { Value-Added Networks }\end{array}$ & 2005 & 2198 \\
\hline Bowersox and Closs & Supply Chain Logistics Management & 2009 & 1509 \\
\hline $\begin{array}{l}\text { Monczka, Handfield, } \\
\text { Giunipero, and } \\
\text { Patterson }\end{array}$ & Purchasing and Supply Chain Management & 2015 & 1714 \\
\hline van Weele & $\begin{array}{l}\text { Purchasing and Supply Chain Management: Analysis, } \\
\text { Strategy, Planning and Practice }\left(5^{\text {th }} \text { ed.) }\right.\end{array}$ & 2010 & 1129 \\
\hline Shapiro & Modeling the Supply Chain & 2007 & 992 \\
\hline $\begin{array}{l}\text { Tayur, Ganeshan and } \\
\text { Magazine }\end{array}$ & Quantitative Models for Supply Chain Management & 1999 & 661 \\
\hline
\end{tabular}

Table 4. Content of popular SCM textbooks

\begin{tabular}{|c|c|c|c|c|c|c|c|}
\hline Topics & 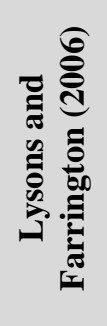 & 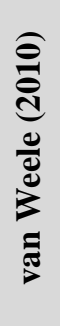 & 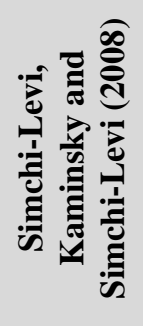 & 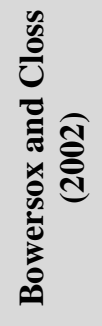 & 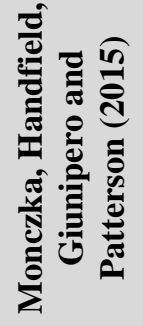 & 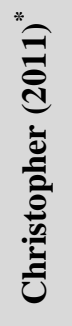 & 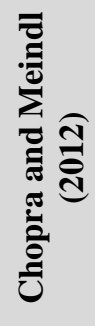 \\
\hline SC Principles, Drivers, Metric, and Capabilities & & & $\checkmark$ & $\checkmark$ & & $\checkmark$ & $\checkmark$ \\
\hline SC Performance Measurement & & $\checkmark$ & & $\checkmark$ & $\checkmark$ & $\checkmark$ & $\checkmark$ \\
\hline SC Strategic Management & & $\checkmark$ & $\checkmark$ & $\checkmark$ & $\checkmark$ & & $\checkmark$ \\
\hline Information Technology for SCM & & & $\checkmark$ & $\checkmark$ & $\checkmark$ & & $\checkmark$ \\
\hline SCM Strategies and Paradigms & $\checkmark$ & & & $\checkmark$ & $\checkmark$ & $\checkmark$ & \\
\hline SC Coordination & & & & & & $\checkmark$ & $\checkmark$ \\
\hline SC Integration & & & & $\checkmark$ & $\checkmark$ & $\checkmark$ & \\
\hline Procurement, Purchasing, and Outsourcing in SC & $\checkmark$ & $\checkmark$ & & $\checkmark$ & $\checkmark$ & & \\
\hline Distribution Network & $\checkmark$ & & $\checkmark$ & $\checkmark$ & & & $\checkmark$ \\
\hline SC Network Design & & & $\checkmark$ & & & & $\checkmark$ \\
\hline Forecasting & & & & & & & $\checkmark$ \\
\hline Advanced Aggregate Planning and Scheduling & & & & $\checkmark$ & & & $\checkmark$ \\
\hline Inventory Management and Control & $\checkmark$ & & $\checkmark$ & $\checkmark$ & $\checkmark$ & $\checkmark$ & $\checkmark$ \\
\hline Supply and Demand Planning & $\checkmark$ & & $\checkmark$ & & & $\checkmark$ & $\checkmark$ \\
\hline Transportation & & & & $\checkmark$ & & & $\checkmark$ \\
\hline Supplier Relationship Management & $\checkmark$ & $\checkmark$ & & & $\checkmark$ & $\checkmark$ & $\checkmark$ \\
\hline
\end{tabular}




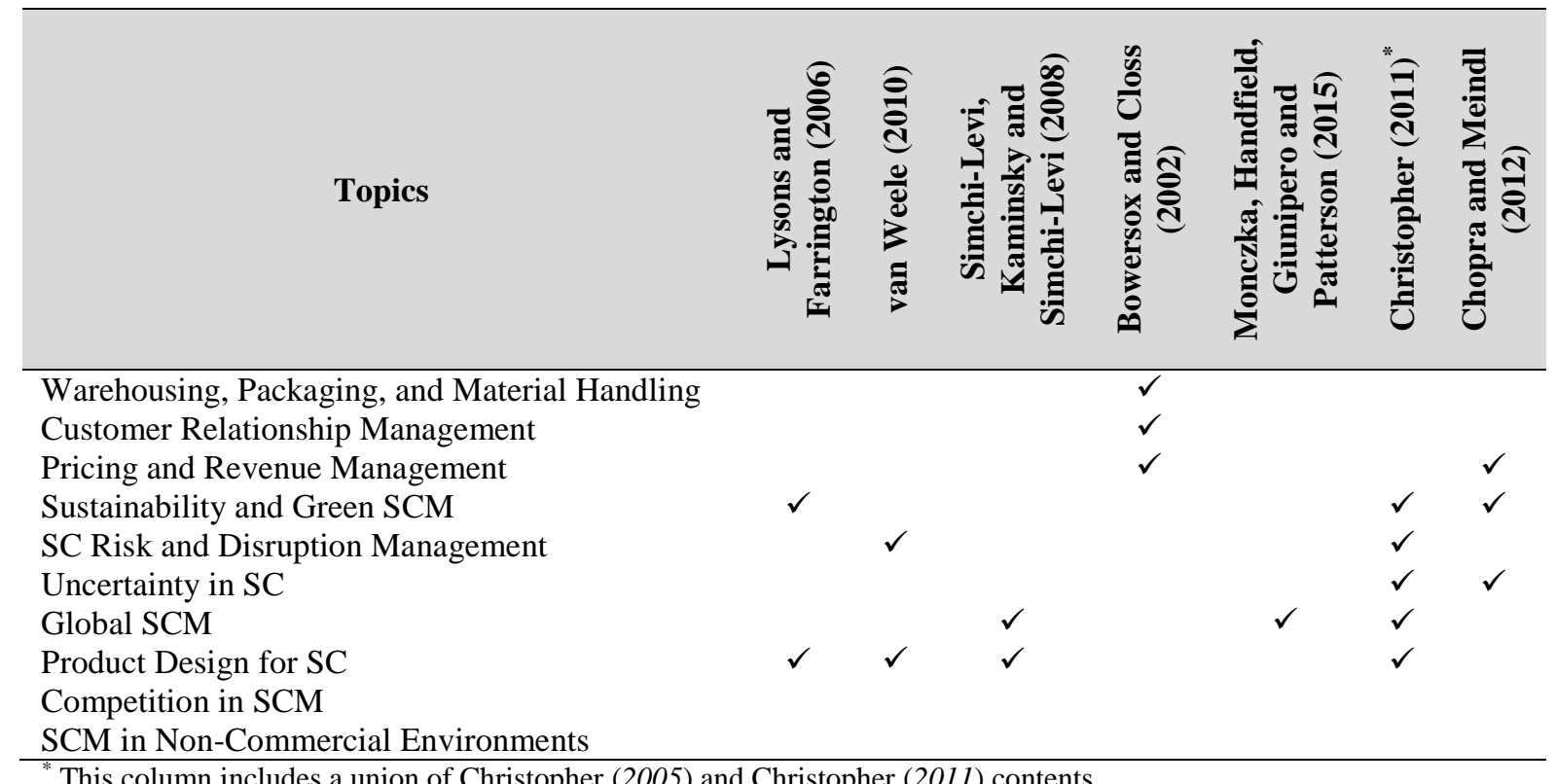

\section{SCM Journal Articles}

Figure 1 shows the number of SCM articles published in peer-reviewed academic journals from 1982 to 2015 . This shows the limited interest in the topic until the late 1990s followed by a dramatic increase in popularity in the 2000s, which has stabilized since 2010. This would suggest SCM is starting to reach the mature phase of its lifecycle and new SCM ideas and concepts need to be explored and published to ensure that it does not start to decline in popularity and become a 'management fad'. Table 5 shows the top 20 peer-reviewed academic journals that have published the highest number articles on SCM since 1982. As one would expect, most of these journals have either a strong SCM or Operations Management (OM) focus (12 journals and eight of the top ten). However, the quantitative research methodologies that are often used to investigate SCM issues and problems mean that another major outlet for SCM research is journals with a focus on operations research and management science (eight journals).

\subsection{Popular and emerging subject areas}

Table 6 summarizes the subject areas (and relevant sub-areas) covered within the SCM articles published to date, whilst Figure 2 shows the change in popularity of these different topics over the last twenty years grouped by their level of popularity. The popularity is measured using the yearly ratio of papers published in each area of SCM (counting appearance of corresponding keywords) with respect to the total number of papers published on SCM. Based on these figure, one could categorize SCM areas into five categories as follows: 


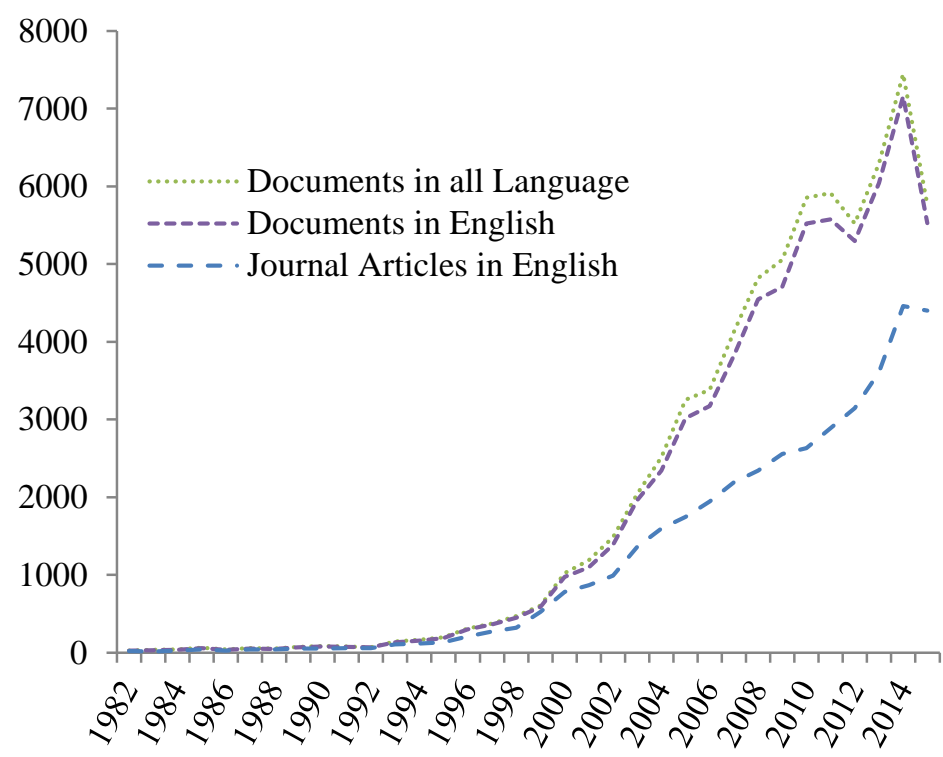

Figure 1. Number of SCM documents published each year (1982-2015)

Table 5. SCM articles published within academic journals (1982-2015)

\begin{tabular}{clr}
\hline Rank & Journal & \# Papers \\
\hline 1 & International Journal of Production Economics & 1350 \\
2 & International Journal of Production Research & 940 \\
3 & European Journal of Operational Research & 824 \\
4 & Supply Chain Management & 656 \\
5 & International Journal of Physical Distribution and Logistics Management & 430 \\
6 & Journal of Cleaner Production & 369 \\
7 & Production Planning and Control & 332 \\
8 & International Journal of Logistics Systems and Management & 327 \\
9 & Computers and Industrial Engineering & 303 \\
10 & Production and Operations Management & 296 \\
11 & Computer Aided Chemical Engineering & 286 \\
12 & International Journal of Operations and Production Management & 272 \\
13 & Expert Systems with Applications & 255 \\
14 & International Journal of Advanced Manufacturing Technology & 249 \\
15 & Journal of Operations Management & 244 \\
16 & Management Science & 216 \\
17 & Transportation Research Part E Logistics and Transportation Review & 207 \\
18 & Manufacturing Computer Solutions & 196 \\
19 & Industrial Management and Data Systems & 190 \\
20 & Automotive Industries AI & 181 \\
\hline
\end{tabular}

Strong growth: The most prominent areas in this category are risk management and sustainability areas with a strong and steady growth since 2001 and 1995, respectively (see Figure 2, lines g and d). In addition, global SC and safety issues have received increasing attention over the past decade. These observations are strongly related to the world-wide concerns over globalization, environmental issues, and business uncertainty in today's economy. 
Table 6. SCM subject areas and sub-areas

\begin{tabular}{|c|c|c|}
\hline General area & \multicolumn{2}{|c|}{ Sub-areas } \\
\hline 1. Inventory & $\begin{array}{l}\text { - Management } \\
\text { - Control } \\
\text { - Replenishment } \\
\text { - Lot sizing } \\
\text { - EOQ }\end{array}$ & $\begin{array}{l}\text { - Batch } \\
\text { - Lead time } \\
\text { - Backordering } \\
\text { - Demand/Order/Capacity }\end{array}$ \\
\hline 2. Performance & $\begin{array}{l}\text { - Evaluation } \\
\text { - Benchmarking } \\
\text { - Assessment }\end{array}$ & $\begin{array}{l}\text { - Measurement } \\
\text { - Auditing }\end{array}$ \\
\hline $\begin{array}{l}\text { 3. Information (supply chain } \\
\text { communication system) }\end{array}$ & $\begin{array}{l}\text { - Information Sharing } \\
\text { - RFID (Technology, ...) } \\
\text { - Communication } \\
\text { technologies } \\
\text { - Traceability } \\
\text { - E-commerce } \\
\text { - B2B } \\
\text { - E-business } \\
\text { - Information asymmetry } \\
\text { - E-procurement } \\
\text { - Information exchange } \\
\text { - DSS }\end{array}$ & $\begin{array}{l}\text { - Knowledge sharing } \\
\text { - web-based } \\
\text { - Internet } \\
\text { - Tracking } \\
\text { - Monitoring } \\
\text { - Value of information } \\
\text { - Data mining } \\
\text { - Decentralized } \\
\text { - Electronic commerce } \\
\text { - Virtual } \\
\text { - Visibility }\end{array}$ \\
\hline 4. Processes & $\begin{array}{l}\text { - Production } \\
\text { - Manufacturing } \\
\text { - Distribution } \\
\text { - Ordering } \\
\text { - Sales } \\
\text { - Procurement }\end{array}$ & $\begin{array}{l}\text { - Purchasing } \\
\text { - Transportation } \\
\text { - Maintenance } \\
\text { - Vehicle Routing } \\
\text { - Shipment }\end{array}$ \\
\hline 5. Supply-side & $\begin{array}{l}\text { - Supplier } \\
\text { - Outsourcing } \\
\text { - Supplier selection } \\
\text { - Sourcing } \\
\text { - Vendor }\end{array}$ & $\begin{array}{l}\text { - Supplier evaluation } \\
\text { - Vendor selection } \\
\text { - 3PL (Third-Party Logistics) } \\
\text { - Warehousing/ Warehouse }\end{array}$ \\
\hline 6. Supply chain design & - Network Design & - Location \\
\hline 7. Coordination/Coordinated & - & \\
\hline 8. Integration/Integrated & - Leadership & \\
\hline 9. Strategy/Strategies & - & \\
\hline 10. Global supply chain & $\begin{array}{l}\text { - Global } \\
\text { - International }\end{array}$ & - Globalization/ \\
\hline 11. SC Risk management & $\begin{array}{l}\text { - Uncertainty } \\
\text { - Stochastic } \\
\text { - Robust } \\
\end{array}$ & $\begin{array}{l}\text { - Fuzzy } \\
\text { - Disruption }\end{array}$ \\
\hline 12. Quality/Quality assurance & - & \\
\hline 13. Sales & $\begin{array}{l}\text { - Pricing } \\
\text { - Bargaining } \\
\text { - Auction } \\
\text { - Negotiation } \\
\text { - Discount } \\
\end{array}$ & $\begin{array}{l}\text { - Forecasting } \\
\text { - Market } \\
\text { - Customer satisfaction } \\
\text { - Advertising } \\
\text { - Revenue management }\end{array}$ \\
\hline 14. Service & - & \\
\hline 15. Flexibility & - & \\
\hline 16. Negotiation & $\begin{array}{l}\text { - Contracts } \\
\text { - Trust }\end{array}$ & - Contracting \\
\hline 17. Scheduling & - Scheduling & - Sequencing \\
\hline 18. Dynamics & $\begin{array}{l}\text { - Bullwhip effect } \\
\text { - Control Theory }\end{array}$ & - System Dynamics \\
\hline $\begin{array}{l}19 . \\
\text { Collaboration/Cooperation/Relationships }\end{array}$ & $\begin{array}{l}\text { - Supplier relationship } \\
\text { - Buyer-supplier }\end{array}$ & $\begin{array}{l}\text { - Inter-organizational } \\
\text { - Buyer-Supplier }\end{array}$ \\
\hline
\end{tabular}




\begin{tabular}{|c|c|c|}
\hline & $\begin{array}{l}\text { relationships } \\
\text { - Buyer-Seller } \\
\text { - Manufacturer-retailer } \\
\text { - Production-distribution }\end{array}$ & $\begin{array}{l}\text { - Incentives } \\
\text { - Partnership } \\
\text { - Alliances } \\
\text { - Production-inventory }\end{array}$ \\
\hline 20. Sustainability & $\begin{array}{l}\text { - Reverse logistics } \\
\text { - Sustainable } \\
\text { - Social } \\
\text { - Closed-loop } \\
\text { - Green } \\
\text { - Remanufacturing }\end{array}$ & $\begin{array}{l}\text { - Environmental management } \\
\text { - Recovery } \\
\text { - Return } \\
\text { - Environment/ } \\
\text { Environmental } \\
\text { - Perishable } \\
\end{array}$ \\
\hline 21. Competition/Competing & - & \\
\hline 22. Implementation & - & \\
\hline 23. Safety/Emergency/Security & - & \\
\hline 24. Small to medium-sized enterprises & - & \\
\hline 25. Humanitarian & $\begin{array}{l}\text { - Relief } \\
\text { - Disasters }\end{array}$ & - Humanitarian \\
\hline 26. Decision-Making Level & $\begin{array}{l}\text { - Operational } \\
\text { - Tactical }\end{array}$ & - Strategic \\
\hline
\end{tabular}



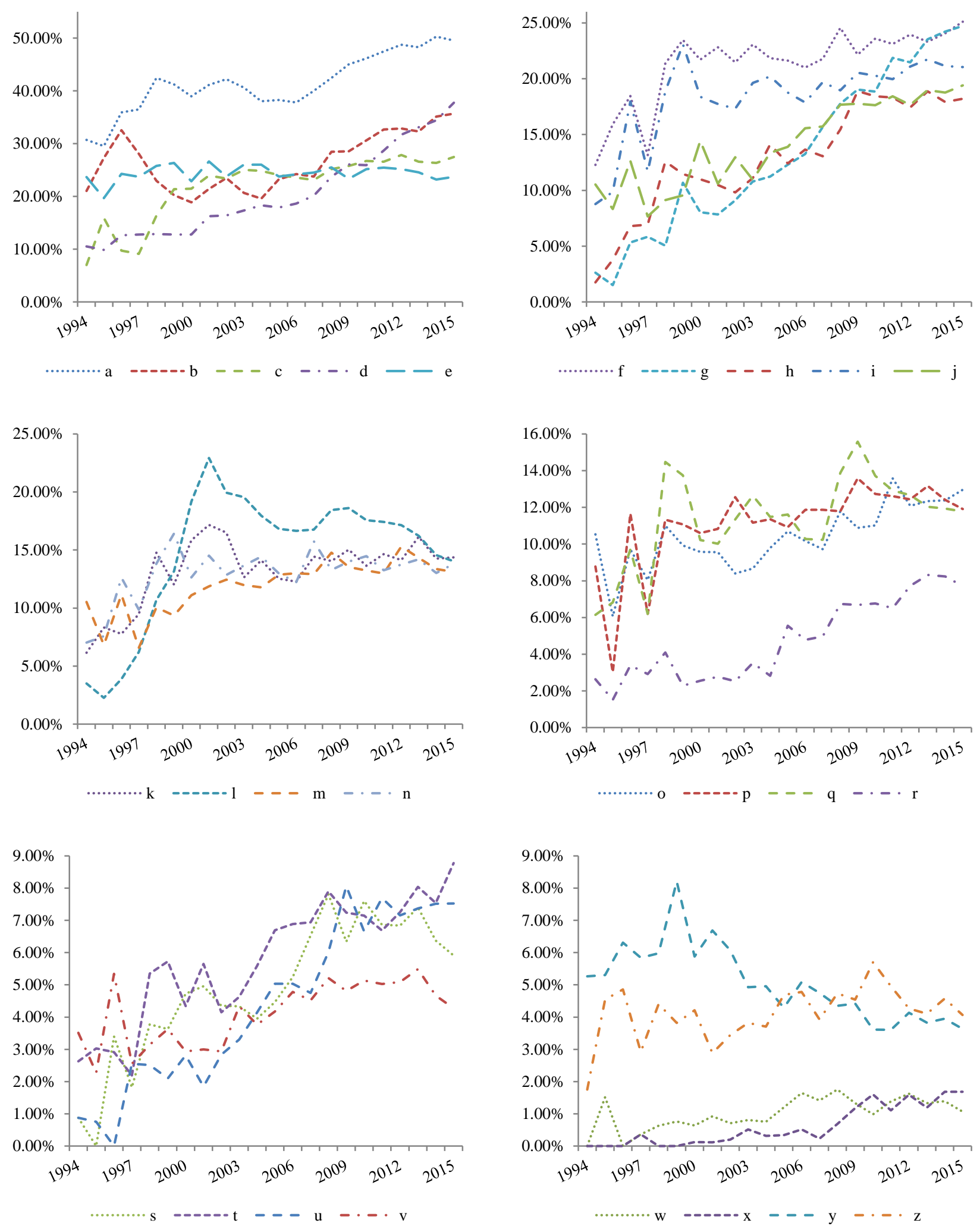

Figure 2. Trends of different areas within SCM between 1994 and 2015: a) Processes, b) Performance, c) Sales, d) Sustainability, e) Inventory, f) Supply-Side, g) Risk Management, h) Global SCM, i) Strategy, j) Implementation, k) Integration, l) Information, m) Collaboration, n) Decision-Making Level, o) Quality, p) Service, q) Competition, r) SC Design, s) Coordination, t) Negotiation, u) Safety, v) Dynamics, w) SME, x) Humanitarian, y) Scheduling, z) Flexibility

Slight growth: Seven areas of performance, SC implementation, SC design, coordination, negotiation, dynamics, and humanitarian logistics have received positive attention from researchers 
over the past decade. While some these areas such as SC design, coordination, and performance could be considered matured research areas, others such as humanitarian logistics and SC dynamics are of high importance that requires more attention over the next years.

Steady: This category includes various areas such as processes, collaboration, decision making, quality, service, competition, small- and medium-sized enterprises (SMEs), and flexibility.

Slight decline: Multiple areas including sales, inventory, supply-side, strategy, integration, and information have received less attention during the past decade.

Strong decline: The only area in SCM with clearly strong decline is scheduling in SCM. This decline could be attributed to the fact that most of scheduling-related decisions are operational-level decisions that are usually made independently by each SC member, while other supply chain decisions are interconnected by actions and behaviors of different SC members. Hence, a level of saturation has been research for the area of scheduling with SCM literature.

We have found another classification on subject areas of SCM. We searched SCOPUS for journal articles (including in-press article) including "Supply Chain". Table 7 shows main subject areas of the papers with respect to SCOPUS classification. According to Table 7, SCM paper publications have the highest coverage in the engineering subject area. Figure 3 distinguishes the number of publications in the top three popular subject areas (namely, 1- business, management and accounting, 2- engineering, and 3-decision sciences) over the past 10 years.

Table 7. Main subject areas of Supply Chain publications (SCOPUS classification)

\begin{tabular}{lrr}
\hline Subject area & \# Papers & \multicolumn{1}{l}{$\%$} \\
\hline Engineering & 16984 & 26.52 \\
Business Management and Accounting & 13691 & 21.37 \\
Decision Sciences & 8212 & 12.82 \\
Computer Science & 6966 & 10.88 \\
Social Sciences & 4076 & 6.36 \\
Mathematics & 3096 & 4.83 \\
Economics Econometrics and Finance & 3012 & 4.70 \\
Environmental Science & 2922 & 4.56 \\
Others & 5093 & 7.95 \\
\hline
\end{tabular}




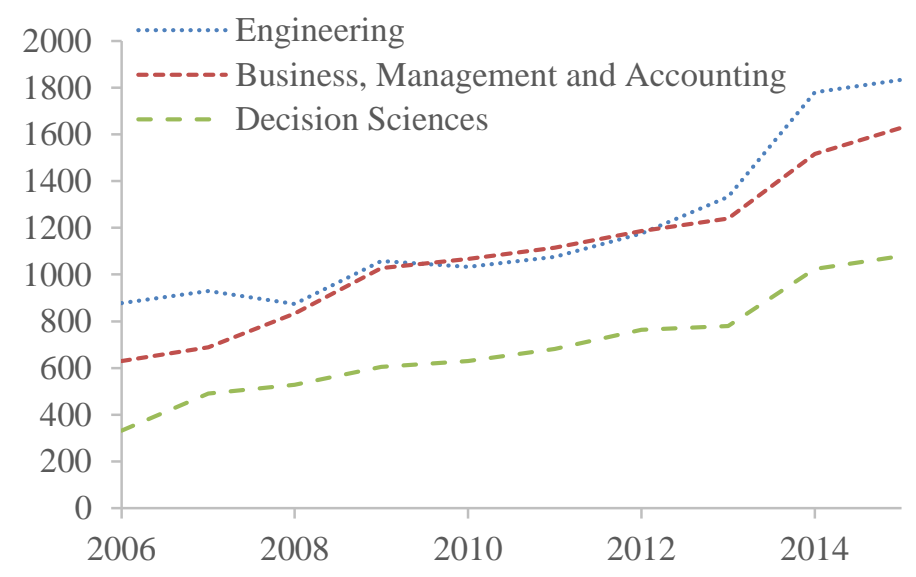

Figure 3. Supply Chain publication trends in the top 3 most popular subject areas

\subsection{Popular and emerging research tools and techniques}

As mentioned earlier, quantitative tools and techniques are often used to research SCM. Table 8 summarizes the ones most widely used to date based on their frequencies as a journal article keyword. This shows that optimization, simulation and fuzzy theory tools and techniques are the ones most often used. Optimization is used to help understand how to make better decisions within a SC, while simulation is used to evaluate the effects of uncertainty and/or test new ideas for managing complex supply chains. In addition, other techniques seem to be emerging in popularity. For example, game theory is being increasingly used to understand the cooperation and conflict between multiple agents within a SC. Also, multi-attribute decision making and multi-objective optimization techniques are starting to be used to better predict the impact of conflicting objectives and decisions within a SC, while systems dynamics is more frequently used to understand the behavior of supply chains over time.

Table 8. Popular SCM research tools and techniques

\begin{tabular}{llr}
\hline Rank & Tool/Technique & \# Papers \\
\hline 1 & Optimization & 2531 \\
2 & Simulation & 1543 \\
3 & Fuzzy (theory) & 891 \\
4 & Game theory & 648 \\
5 & Forecasting & 578 \\
6 & Heuristics, Metaheuristics. Matheuristics, and Hyper-Heuristics & 552 \\
7 & Linear Programming & 516 \\
8 & Multi-Attribute Decision Making (including all techniques) & 508 \\
9 & Genetic and Evolutionary Algorithms & 508 \\
10 & Multi-objective optimization & 412 \\
11 & Approximation (algorithm) & 220 \\
12 & Decomposition & 230 \\
13 & Mixed-Integer Linear Programming (MILP) & 214 \\
14 & Neural Network & 155 \\
15 & Systems Dynamics & 198 \\
16 & Dynamic Programming & 229 \\
\hline
\end{tabular}




\begin{tabular}{lll}
\hline 17 & DEA (Data Envelopment Analysis) & 198 \\
18 & Simulated Annealing, Tabu Search, and Variable Neighborhood Search & 179 \\
19 & Stochastic Programming and Robust Optimization & 323 \\
20 & Nonlinear Programming & 110 \\
\hline
\end{tabular}

\subsection{Popular and emerging management tools and techniques}

Table 9 shows the most popular management tools and techniques investigated within the SCM research to date. This shows that coordination/synchronization is frequently investigated as an approach to help to coordinate ordering and lead time decisions across a SC. Just-in-Time (JIT), Vendor-Managed Inventory (VMI), Make-to-Order/Build-to-Order, and postponement have been studied as alternative methods for managing information, material and money flows across a SC and support market needs. Lean is used to understand how non-value added processes and practices can be eliminated within a SC, Agility to help it respond rapidly to changing market demands, Robustness to increase its resilience to external risks and uncertainties that it might face, and Stability to ensure it has the right relationships with partners and suppliers to maintain a sustainable flow of information, material and money across the SC. As a result, most of the SCM articles published to date are concerned with management tools and techniques that try to improve the overall performance of the SC by increasing sales, reducing costs and/or reducing inventory levels across the chain.

Table 9. Popular SCM management tools and techniques

\begin{tabular}{llr}
\hline Rank & Journal & \# Papers \\
\hline 1 & Coordination/Synchronization & 2394 \\
2 & Lean (Production/Supply Chain) & 524 \\
3 & Agility & 520 \\
4 & Just-in-time & 376 \\
5 & Reliability & 321 \\
6 & Stability & 313 \\
7 & VMI (Vendor-Managed Inventory) & 308 \\
8 & Robustness & 300 \\
9 & Make-to-order/Build-to-order & 222 \\
10 & Postponement & 136 \\
\hline
\end{tabular}

\subsection{Popular and emerging industries to study}

Table 10 shows the different industries that have been studied over the last twenty years and Figure 4 shows how the popularity of these has changed over time grouped by their level of popularity. This shows that food, energy, and automotive industries are the most widely studied industries followed by agricultural, retail, and chemical. It is likely that these will remain popular in the future given the complexity of the supply chains that they manage, the challenges they face, and the sophisticated nature of the solutions that their analysts have developed to overcome these issues. However, it is interesting to see studies on aid agencies are emerging in recent years to understand 
the social and environmental challenges and impact of different SCM practices on humanitarian logistics, which suggests that this might start to become an industry to explore further in the future.

Table 10. Comparison of the number of the reports on SCM application in different industries during 1982-2015.

\begin{tabular}{lrr}
\hline Industry & \# Papers & \% \\
\hline Food & 608 & 20.39 \\
Energy & 566 & 18.98 \\
Automotive & 427 & 14.32 \\
Agricultural & 315 & 10.56 \\
Retail & 262 & 8.79 \\
Chemical & 225 & 7.55 \\
Pharmaceutical & 117 & 3.92 \\
Textile & 102 & 3.42 \\
Aid agencies & 74 & 2.48 \\
Telecommunication & 70 & 2.35 \\
Defense & 63 & 2.11 \\
Semiconductor & 60 & 2.01 \\
Aerospace & 55 & 1.84 \\
Petroleum & 38 & 1.27 \\
\hline
\end{tabular}

\section{Areas for Future SCM Research}

Despite the significant amount of SCM research that has been conducted and the high number of published books and journal articles over the past decades, there are still some areas and applications that have not yet been explored or require further exploration as new business environments and industry trends emerge. Generally speaking, these areas could be divided into two separate categories of general and specific research areas. While, general research areas could be applicable to many types of SCs (i.e., manufacturing or service supply chains), specific research areas are devoted to specific supply chains that function as part of service industry. This categorization is mostly motivated by the recent emerging applications of SCM in the service industry. Next, we will discuss these research areas in sections 5.1 and 5.2 devoted to research trends within different SCM areas and research trends within application areas, respectively.

\subsection{Future trends within subject areas}

A number of gaps within the existing literature that present areas worthwhile for further exploration are now discussed.

Security. Although a significant amount of research has looked at the information and financial requirements to create effective collaboration and decision making across a SC (such as Cao et al. 
2010 and Lehoux et al. 2014), no research to date has investigated the security issues that might present and how they can be overcome as organizations make planning, negotiation and pricing decisions more collaboratively across a SC (Hong et al. 2014). This is an increasingly important concern within businesses in general (Upton and Creese, 2014) and its implications for effective SCM need to be better understood.

Insourcing. Deciding whether to 'make' or 'buy' is one of the most important decisions can organizations has to make (Hill and Hill, 2012). This topic needs to be continually investigated as markets become more dynamic, the world becomes more connected, business environments change and new industry trends emerge. After years of outsourcing, a trend for insourcing is starting to emerge as organizations attempt to reduce the level of risk and disruption within their SC, develop new capabilities so they can compete differently, respond to changes in government legislation. However, research needs to be conducted to understand the impact of these decisions and the best practices to pursue when making them.
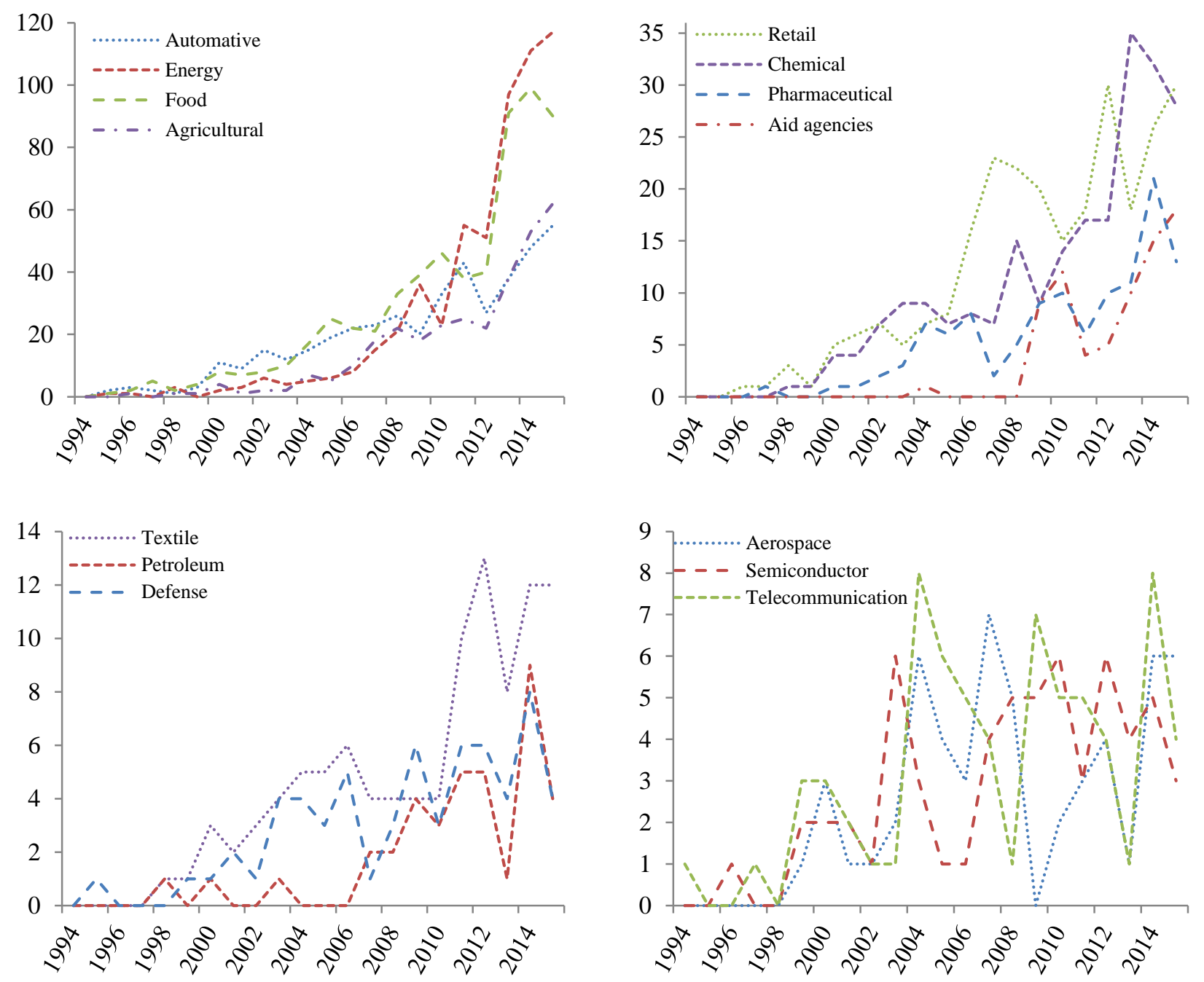

Figure 4. Trends of application of SCM in different industries during 1994-2015 
Sustainability. A significant part of the social, economic, and environmental impact of an organization occurs within its supply chain (Nikbakhsh 2009; Brandenburg et al. 2014). This is an increasingly important area of SCM research and is likely to become more important in years to come as organizations have to respond to new governmental and international regulations, increased social and customer awareness, and changing market needs (New, 2010). While the SCM literature has made a great contribution to understanding the environmental aspects of sustainability and incorporating them into SCM theory and practice, there is still a considerable lack of effective attention to social issues. Understanding how best to do this requires a multidisciplinary framework that draws from various different academic disciplines (other than operations management, logistics, and purchasing) such as sociology, computing, economics, philosophy, political science, health, construction, and psychology to understand the impact that SC decisions can have on the societies and environments in which they operate.

Competition. Understanding where competition can emerge from, how to mitigate against it and how to respond to it are increasingly important questions as supply chains become more complex and global, new technologies emerge and resources become more accessible. Recent examples of competition emerging from within a supply chain (from a supplier or a customer) mean that previous research simply looking at competition between supply chains might be out-of-date and no longer enough for many organizations. Therefore new research needs to be completed to see if traditional competition theories are still relevant or if new ones need to be developed as the competitive landscape changes and evolves (Farahani et al. 2014; Rezapour et al. 2014). In addition, there are still important gaps in the literature regarding multi-criteria analysis of competition as well as randomness/uncertainty of competition parameters.

Risk and disruption management. As supply chains become more complex and global, the level of demand, supply, cost, and revenue uncertainty within them increases (Yang and Yang, 2010; Simangunsong et al. 2012; Hosseini et al. 2014), and so does the threat of risk and disruption across the chain (Nikbakhsh 2012). Understanding the factors that can create uncertainty and how to best mitigate against risk and disruption is an ongoing challenge as business environments change (Liberatore et al. 2013; Hasani et al. 2015; Farahani et al. 2014). Consequently, organizations continually look for ways to improve their performance under uncertainty (Hill et al. 2012) as they lean their processes and postpone decisions within the chain (Tang, 2006; Saghiri and Hill, 2014). Future research needs to understand both the impact of external (such as market, economic, political and technological forces) and internal (such as SC design, information sharing, forecasting and collaboration) factors that can potentially expose a SC to risks, disrupt its daily operations, or change how it needs to operate or perform. In addition over the past decade, improvement in computational facilities and optimization techniques have enabled SC managers to 
deal with SC risk and disruptions via more sophisticated quantitative tools such as stochastic programming and robust optimizations. However, there is still a lot to do in this field as there are many newly problems introduced due to considering new issue in SCM such as disasters, global SC, sustainability, and competition (Liberatore et al. 2013; Hasani et al. 2015; Farahani et al. 2014).

Human behavior. Previous research has focused on understand the role and impact of different structures, systems, and processes within a supply chain. As a result, the impact of the culture of the different organizations within the chain, the relationships and trust between them, and where power resides within a chain are not fully understood (Tokar 2010). For example, it would be useful to better understand the factors that influence how SC managers think, make decisions and negotiate with other organizations in the chain (Carter et al. 2007). Although some research has started to be published in the last three years, this is still an area that requires further exploration.

\subsection{Future trends within application areas}

SCM has traditionally been studied in a manufacturing context as manufacturing organizations were one of the first to outsource parts of their business and use suppliers in different parts of the world. Although many service organizations now also have complex and global supply chains, little research in these industries has been conducted to understand if they face different challenges or should use different approaches. Some service industries, which would be of top priority for deeper understanding, are now discussed.

Healthcare. The SCs used within healthcare organizations have changed significantly in recent years as markets open up, competition increases, lean initiatives are pursued, and government legislation changes (de Vries and Huijsman 2011). However, as with most professional services, the SCs within these industries are usually managed by medical professionals rather than SC professionals. As a result, this makes this an interesting industry to understand and one where research could significantly help practitioners.

Disaster and humanitarian. Even though considerable advances have been made in disaster and humanitarian supply chains in recent years, there are still many opportunities for further research (Nikbakhsh and Farahani, 2011). For example, most studies to date have focused on the preparation, mitigation, and response phases of humanitarian logistics and ignored the recovery phase, which is in many ways more important than the initial response (Leiras et al. 2014). There are also (often public) charities involved in humanitarian operations that have very different levels of access to resources, capabilities, and technologies and operate in very different business environments than the private organizations on which most previous research has been conducted. Therefore, further research needs to be conducted to understand the problems these organizations face, how they can be overcome and what they can learn from other industries (Leiras et al. 2014). 
Small and medium-sized enterprises (SMEs). Most research to date has also been conducted in large organizations with access to a large amount of resources serving high volume markets and managing complex SCs. Although the SCs of SMEs are often simpler, they often serve more complex and dynamic markets with more specialist and complex products/services and have to operate with more limited access to resources and funds in comparison to large enterprises. This can make them reluctant to adopt SCM practices developed by large enterprises (Vaaland and Heide 2007). Instead, they have often developed export clusters, horizontal co-operations, vertical integrations, long-term partnerships and strategic collaborations to enable them to compete against large organizations (Lenny Koh et al. 2007; Vaalvand and Heide 2007). As a result, their SCs have very different structures to those of large organizations, which create different challenges and opportunities. Future research needs to better understand these if it is to develop theories and concepts that are relevant to the characteristics of their industry.

At the end of this section, it is worth mentioning that these three new applications of SCM are parts of the challenges in SCM that developing countries face due to the smaller economy size, lack of infrastructures, and inefficiencies of the healthcare and disaster operations systems. Consequently, there should be a focus on the needs and characteristics of these countries to develop more relevant and practical models and solutions. In addition, developing educational programs on SCM-related issues of these applications could help these countries with improving their systems efficiency and effectiveness. To achieve this, relevant success stories and case studies could be of interest (Mbohwa 2010; Ortuño et al. 2011; Abban et al. 2013. Sheppard et al. 2013; Pazirandeh and Norrman 2014).

\section{Conclusions and Limitations of the Research}

Supply chain management has been one of the most important management philosophies since 1982 as it has gained considerable attention from both practitioners and academics around the world. Although logistics is the main building block of every supply chain, supply chain management differs from logistics in requiring an integrated and coordinated approach to managing flows of a) material, b) information, and c) money in competitive environments.

In this paper, we present an overview of SCM trends between 1982 and 2015 and the possible promising future directions in three domains: textbooks, research, and implementation. After discussing the research scope, most-widely cited books and textbooks on SCM are introduced. Next, published peer-reviewed journal papers are analyzed using various criteria including important journals, trends of different areas within SCM, as well as most prominent techniques and philosophies in SCM research. Then, implementation of SCM concepts and practices around the world are investigated based on the relevant industries. Finally, some promising future research 
areas with SCM are introduced. The first important issue is how organizations should manage security, insourcing, sustainability, competition, risk/disruption and human behavioral issues within their supply chains. In addition, it is necessary understand the particular practices, challenges and opportunities within newer applications of SCM such as healthcare, disaster and humanitarian and small and medium enterprises industries. These recommendations could be used by SCM academics and professionals to redefine the focus point of their research and application of SCM.

In the end, limitations of this paper are outlined. First, this study does not include papers in the pipeline (i.e., papers under review by the journals). Second, it does not cover conference papers not published in any journal. Other limitations of this study are as follows:

- Presence (absence) of a desired term in title, abstract, and keywords of a journal paper does not necessarily indicate that specific paper is (not) about that term. Therefore, there is possibility that some of the numbers given in this research are underestimation or overestimation of corresponding real numbers.

- We have searched over title, abstract, and keywords of thousands of journal papers. While in some cases, we have checked some of the papers carefully, we have not read all of these papers and relied on the descriptive statistics to derive facts and insights about supply chain management.

- Over the years, the number of publishing outlets for scientific research has increased considerably (Larsen and von Ins, 2010; Smart, 2014). This could possibly have a positive effect on the number of papers that has been published on SCM over the years (i.e., more journals, more papers accepted). In particular, the increase in the number of published paper could be partially encouraged by the exciting huge number of outlets, instead of the mere scientific and applied relevance of the field. Consequently, this phenomenon possibly could have created a bias in our analysis of trends and findings.

\section{References}

Abban, R., Omta, S.W.F., Aheto, J.B.K. \& Scholten, V.E., 2013. Connecting the dots: A multiple case study of the network relationships of small and medium-sized enterprises (SMEs) in the non-traditional agricultural export (NTAE) sector of Ghana. African Journal of Economic and Management Studies, 4 (1), 74-94.

Abbasi, M. \& Nilsson, F., 2012. Themes and challenges in making supply chains environmentally sustainable. Supply Chain Management: An International Journal, 17 (5), 517-530.

Ahumada, O. \& Villalobos, J.R., 2009. Application of planning models in the agri-food supply chain: a review. European Journal of Operational Research, 196 (1), 1-20. 
Akyuz, G.A. \& Erkan, T.E., 2010. Supply chain performance measurement: A literature review. International Journal of Production Research, 48 (17), 5137-5155.

Alfalla-Luque, R. \& Medina-López, C., 2009. Supply chain management: Unheard of in the 1970s, core to today's company. Business History, 51 (2), 202-221.

Ashby, A., Leat, M. \& Hudson-Smith, M., 2012. Making connections: A review of supply chain management and sustainability literature. Supply Chain Management: An International Journal, 17 (5), 497-516.

Bekkering, J., Broekhuis, A.A. \& van Gemert, W.J.T., 2010. Optimisation of a green gas supply chain - A review. Bioresource Technology, 101 (2), 450-456.

Boone, C.A., Drake, J.R., Bohler, J.A. \& Craighead, C.W., 2007. Supply chain management technology: A review of empirical literature and research agenda. International Journal of Integrated Supply Management, 3 (2), 105-124.

Bowersox, D.J. \& Closs, D.J., 2002. Supply chain logistics management New York, NY: McGraw-Hill.

Brandenburg, M., Govindan, M., Sarkis, J. \& Seuring, S., 2014. Quantitative models for sustainable supply chain management: Developments and directions. European Journal of Operational Research, 233 (2), 299-312

Browne, M., Rizet, C., Anderson, S., Allen, J. \& Keita, B., 2005. Life cycle assessment in the supply chain: A review and case study. Transport Reviews, 25 (6), 761-782.

Burgess, K., Singh, P.J. \& Koroglu, R., 2006. Supply chain management: A structured literature review and implications for future research. International Journal of Operations and Production Management, 26 (7), 703-729.

Cao, Z., Huo, B., Li, Y., \& Zhao, X., 2015. Competition and supply chain integration: A taxonomy perspective. Industrial Management and Data Systems, 115 (5), 923-950.

Carter, C.R. \& Easton, P.L., 2011. Sustainable supply chain management: Evolution and future directions. International Journal of Physical Distribution and Logistics Management, 41 (1), 46-62.

Carter, C.R. \& Rogers, D.S., 2008. A framework of sustainable supply chain management: moving towards new theory. International Journal of Physical Distribution \& Logistics Management, 38 (5), 360-387.

Carter, C.R., Kaufmann, L. \& Michel, A., 2007. Behavioral supply management: a taxonomy of judgment and decision-making biases. International Journal of Physical Distribution \& Logistics Management, 37 (8), 631-669.

Chan, F.T.S., Chan, H.K. \& Qi, H.J., 2006. A review of performance measurement systems for supply chain management. International Journal of Business Performance Management, 8 (2-3), 110-131.

Chen, Z.L., 2010. Integrated production and outbound distribution scheduling: Review and extensions. Operations Research, 58 (1), 130-148.

Chopra, S. \& Meindl, P., 2012. Supply chain management: Strategy, planning \& operation, 4th ed. New Jersey, NJ: Prentice Hall.

Christopher, M., 2005. Logistics and supply chain management: Creating value-added networks, 3rd ed. New York, NY: Financial Times Press. 
Christopher, M., 2011. Logistics and supply chain management, 4th ed. New York, NY: Financial Times Press.

Colicchia, C. \& Strozzi, F., 2012. Supply chain risk management: A new methodology for a systematic literature review. Supply Chain Management: An International Journal, 17 (4), 403-418.

Coyle, T., 2003. Market Trends: Material Control RFID and the Mainstream Supply Chain. Material Handling Management, 58 (9), 47-50.

Croom, S., Romano, P. \& Giannakis, M., 2000. Supply chain management: An analytical framework for critical literature review. European Journal of Purchasing and Supply Management, 6 (1), 67-83.

Cutting-Decelle, A.F., Das, B.P., Young, R.I., Case, K., Rahimifard, S., Anumba, C.J. \& Bouchlaghem, N.M., 2006. Building supply chain communication systems: A review of methods and techniques. Data Science Journal, 5, 29-51.

Daugherty, P.J., 2011. Review of logistics and supply chain relationship literature and suggested research agenda. International Journal of Physical Distribution and Logistics Management, 41 (1), 16-31.

de Vries, J. \& Huijsman, R., 2011. Supply chain management in health services: an overview. Supply Chain Management: An International Journal, 16 (3), 159-165.

Denham, F.C., Howieson, J.R., Solah, V.A., \& Biswas, W.K., 2015. Environmental supply chain management in the seafood industry: past, present and future approaches. Journal of Cleaner Production, 90, 82-90.

Eskandarpour, M., Dejax, P., Miemczyk, J., \& Péton, O., 2015 Sustainable supply chain network design: An optimization-oriented review. Omega, 54, 11-32.

Fahiminia, B., Sarkis, J., \& Davarzani, H., 2015. Green supply chain management: A review and bibliometric analysis. International Journal of Production Economics, 162, 101-114.

Fatemi, M., 2010. Supply chain flexibility: Definition and review. European Journal of Economics, Finance and Administrative Sciences, 20, 140-147.

Farahani, R.Z., Rezapour, S., Drezner, T. \& Fallah, S., 2014. Competitive supply chain network design: An overview of classifications, models, solution techniques and applications. Omega, 45, 92-118.

Fleischmann, M., Bloemhof-Ruwaard, J., Dekker, E., van der Laan, R., van Nunen, J. \& van Wassenhove, L., 1997. Quantitative models for reverse logistics: A review. European Journal of Operational Research, 103 (1), 1-17.

Garfinkel, S.L., Juels, A. \& Pappu, R., 2005. RFID privacy: An overview of problems and proposed solutions. IEEE Security and Privacy, 3 (3), 34-43.

Geary, S., Disney, S.M. \& Towill, D.R., 2006. On bullwhip in supply chains - Historical review, present practice and expected future impact. International Journal of Production Economics, 101 (1), 2-18.

Gimenez, C. \& Tachizawa, E.M., 2012. Extending sustainability to suppliers: A systematic literature review. Supply Chain Management: An International Journal, 17 (5), 531-543.

Giunipero, L., Handfield, R.B. \& Eltantawy, R., 2006. Supply management's evolution: Key skill sets for the supply manager of the future. International Journal of Operations and Production Management, 26 (7), 822-844. 
González-Benitoa, J., Lannelongue, G. \& Alfaro-Tanco, J.A., 2013. Study of supply-chain management in the automotive industry: a bibliometric analysis. International Journal of Production Research, 51 (13), 3849-3863.

Govindan, K., 2013. Vendor managed inventory: A review based on dimensions. International Journal of Production Research, 51 (13), 3808-3835.

Gunasekaran, A. \& Kobu, B., 2007. Performance measures and metrics in logistics and supply chain management: a review of recent literature (1995-2004) for research and applications. International Journal of Production Research, 45 (12), 2819-2840.

Gupta, S., Verma, R. \& Victorino, L., 2006. Empirical research published in production and operations management (1992-2005): Trends and future research directions. Production and Operations Management, 15 (3), 432-448.

Hammami, R., Frein, Y. \& Hadj-Alouane, A.B., 2008. Supply chain design in the delocalization context: Relevant features and new modeling tendencies. International Journal of Production Economics, 113 (2), 614-656.

Hasani, A.A., Zegordi, S.H. \& Nikbakhsh, E., 2015. Robust closed-loop global supply chain network design under uncertainty: The case of the medical device industry. International Journal of Production Research, 53 (5), 1596-1624.

Hassini, E., 2008. Supply chain optimization: Current practices and overview of emerging research opportunities. INFOR: Information Systems and Operational Research, 46 (2), 93-96.

Hill, A.J., Doran, D. and Stratton, R., 2012. How should you stablise your supply chain? International Journal of Production Economics, 135, 870-881.

Hill, A.J. \& Hill, T.J., 2012. Operations Management ( $3^{\text {rd }}$ Edition), Palgrave Macmillan.

Hintsa, J., Gutierrez, X., Wieser, P. \& Hameri, A.-P., 2009. Supply chain security management: An overview. International Journal of Logistics Systems and Management, 5 (3-4), 344-355.

Ho, W., Zheng, T., Yildiz, H., \& Talluri, S., 2015. Supply chain risk management: a literature review. International Journal of Production Research. 53 (16), 5031-5069.

Hong, Y., Vaidya, J. \& Wang, S., 2014. A survey of privacy-Aware supply chain collaboration: From theory to applications. Journal of Information Systems, 28 (1), 243-268.

Hosseini, S., Farahani, R.Z., Dullaert, W., Raa, B., Rajabi, M. \& Bolhari, A., 2014. A robust optimization model for a supply chain under uncertainty. IMA Journal of Management Mathematics, 25 (4), 287-402.

Huan, S.H., Sheoran, S.K. \& Wan, G., 2004. A review and analysis of supply chain operations reference (SCOR) model. Supply Chain Management: An International Journal, 9 (1), 23-29.

Huang, G.Q., Lau, J.S.K. \& Mak, K.L., 2003. The impacts of sharing production information on supply chain dynamics: A review of the literature. International Journal of Production Research, 41 (7), 14831517.

Ilgin, M.A. \& Gupta, S.M., 2010. Environmentally conscious manufacturing and product recovery (ECMPRO): A review of the state of the art. Journal of Environmental Management, 91 (3), 563-591. 
Jede, A. \& Teuteberg, F., 2015. Integrating cloud computing in supply chain processes: A comprehensive literature review. Journal of Enterprise Information Management, 28 (6), 872-904.

Johnson, M.E. \& Whang, S., 2002. E-business and supply chain management: An overview and framework. Production and Operations Management, 11 (4), 413-423.

Juels, A., 2006. RFID security and privacy: A research survey. IEEE Journal on Selected Areas in Communications, 24 (2), 381-394.

Khan, O., Burnes, B., 2007. Risk and supply chain management: creating a research agenda. International Journal of Logistics Management, 18 (2), 197-216.

Ko, M., Tiwari, A. \& Mehnen, J., 2010. A review of soft computing applications in supply chain management. Applied Soft Computing Journal, 10 (3), 661-674.

Kocakoc, I.D. \& Sen, A., 2006. Utilizing surveys for finding improvement areas for customer satisfaction along the supply chain. International Journal of Market Research, 48 (5), 623-636.

Kouvelis, P., Chambers, C. \& Wang, H., 2006. Supply Chain Management research and Production and Operations Management: Review, trends, and opportunities. Production and Operations Management, 15 (3), 449-469.

Kreipl, S. \& Pinedo, M., 2004. Planning and scheduling in supply chains: An overview of issues in practice. Production and Operations Management, 13 (1), 77-92.

Kumar, P., Reinitz, H.W., Simunovic, J., Sandeep, K.P. \& Franzon, P.D., 2009. Overview of RFID technology and its applications in the food industry. Journal of Food Science, 74 (8), 101-106.

Larsen, P.O. \& von Ins, M., 2010. The rate of growth in scientific publication and the decline in coverage provided by Science Citation Index. Scientometrics, 84 (3), 575-603.

Liberatore, F., Pizarro, C., Simón de Blas, C., Ortuño, M.T. \& Vitoriano, B., 2013. Uncertainty in humanitarian logistics for disaster management - A review. In Vitoriano, B., Montero, J. \& Ruan, D. (Eds.) Decision Aid Models for Disaster Management and Emergencies, Berlin, Springer, 45-74.

Lehoux, N., D’Amours, S. \& Langevin, A., 2014. Inter-firm collaborations and supply chain coordination: review of key elements and case study. Production Planning \& Control: The Management of Operations, 25 (10), 858-872.

Leiras , A., de Brito Jr , I., Peres, E.Q., Bertazzo, T.R. \& Yoshizaki, H.T.Y. , 2014. Literature review of humanitarian logistics research: trends and challenges. Journal of Humanitarian Logistics and Supply Chain Management, 4 (1), 95-130.

Lenny Koh, S.C., Demirbag, M., Bayraktar, E., Tatoglu, E. \& Zaim, S., 2007. The impact of supply chain management practices on performance of SMEs. Industrial Management \& Data Systems, 107 (1), 103124.

Lin, C., Choy, K.L., Ho, G.T.S., Chung, S.H. \& Lam, H.Y., 2014. Survey of Green Vehicle Routing Problem: Past and future trends. Expert Systems with Applications, 41 (4 PART 1), 1118-1138.

Lorentz, H. \& Hilmolla, O.P., 2008. Supply chain management in emerging market economies: A review of the literature and analysis of the Russian grocery retail sector. International Journal of Integrated Supply Management, 4 (2), 201-229. 
Lysons, K. \& Farrington, B., 2006. Purchasing and Supply Chain Management, 7th ed. New York, NY: Financial Times Press.

Marasco, A., 2008. Third-party logistics: A literature review. International Journal of Production Economics, 113, 127-147.

Marquès, G., Thierry, C., Lamothe, J. \& Gourc, D., 2010. A review of Vendor Managed Inventory (VMI): from concept to processes. Production Planning \& Control, 21 (6), 547-561.

Mbohwa, C., 2010. Humanitarian logistics: Review and case study of Zimbabwean experiences. Journal of Transport and Supply Chain Management, 4 (1), 176-197.

Meade, L., Sarkis, J. \& Presley, A., 2007. The theory and practice of Reverse Logistics. International Journal of Logistics systems and Management, 3 (1), 56-84.

Meho, L. \& Yang, K., 2007. Impact of data sources on citation counts and rankings of LIS faculty: Web of Science versus Scopus and Google Scholar. Journal of the American Society for Information Science and Technology, 58 (13), 2105-2125.

Mehrjerdi, Y.Z., 2008. RFID-enabled systems: A brief review. Assembly Automation, 28 (3), 235-245.

Meixell, M.J. \& Gargeya, V.B., 2005. Global supply chain design: A literature review and critique. Transportation Research Part E: Logistics and Transportation Review, 41 (6), 531-550.

Melnyk, S.A., Narasimhan, R. \& DeCampos, H.A., 2014. Supply chain design: Issues, challenges, frameworks and solutions. International Journal of Production Research, 52 (7), 1887-1896.

Melo, M.T., Nickel, S. \& Saldanha-da-Gama, F., 2009. Facility location and supply chain management - A review. European Journal of Operational Research, 196 (2), 401-412.

Miles, R. \& Breen, L., 2005. Pharmaceutical supply chain - Update on the current NHS review. Hospital Pharmacist, 12 (3), 105-106.

Mills, J., Schmitz, J. \& Frizelle, G., 2004. A strategic review of supply networks. International Journal of Operations and Production Management, 24 (10), 1012-1036.

Mingersm, J., 2009. Measuring the research contribution of management academics using the Hirsch-index. Journal of the Operational Research Society, 60 (9), 1143-1153.

Monczka, R.M., Handfield, R.B., Giunipero, L.C. \& Patterson, J.L., 2016. Purchasing and Supply Chain Management, 6th ed. Mason, OH: South-Western College/West.

Mondragon, A.E.C., Lyons, A.C., Michaelides, Z. \& Kehoe, D.F., 2006. Automotive supply chain models and technologies: A review of some latest developments. Journal of Enterprise Information Management, 19 (5), 551-562.

More, D. \& Babu, A.S., 2009. Supply chain flexibility: A state-of-the-art survey. International Journal of Services and Operations Management, 5 (1), 29-65.

Morgan, S.D. \& Gagnon, R.J., 2013. A systematic literature review of remanufacturing scheduling. International Journal of Production Research, 51 (16), 4853-4879.

Natarajarathinam, M., Capar, I. \& Narayanan, A., 2009. Managing supply chains in times of crisis: A review of literature and insights. International Journal of Physical Distribution and Logistics Management, 39 (7), 535-573. 
New, S., 2010. The transparent supply chain. Harvard Business Review 88(10), 76-82.

Nikbakhsh, E., 2009. Green supply chain management. In Farahani, R.Z., Asgari, N., \& Davarzani, H. (Eds.) Logistics and Supply Chain Management in International, National and Governmental Environment, Berlin, Springer, 195-220.

Nikbakhsh, E. (2012) Supply chain risk management. In Zanjirani Farahani, R., Rezapour, S., \& Kardar, L. (Eds.), Supply Chain Sustainability and Raw Material Management: Concepts and Processes, Hershey, PA, IGI Global, 176-204.

Nikbakhsh, E. \& Farahani, R.Z., 2011. Humanitarian logistics planning in disaster relief operations. In Zanjirani Farahani, R., Rezapour, S., \& Kardar, L. (Eds.), Logistics Operations and Management: Concepts and Models, Waltham, MA, Elsevier Insights, 291-332.

Ntabe, E.N., LeBel, L., Munson, A.D., \& Santa-Eulalia, L.A., 2015. A systematic literature review of the supply chain operations reference (SCOR) model application with special attention to environmental issues. International Journal of Production Economics, 169, 310-332.

Nurmilaakso, J.M. \& Kotinurmi, P., 2004. A review of XML-based supply-chain integration. Production Planning and Control, 15 (6), 608-621.

OECD, 2002. Frascati Manual - Proposed Standard Practice for Surveys on Research and Experimental Development. Paris Cedex, France: Organisation for Economic Co-operation and Development.

Olson, D.L. \& Wu, D.D., 2010. A review of enterprise risk management in supply chain. Kybernetes, 39 (5), 694-706.

Ortuño, M.T., Tirado, G. \& Vitoriano, B., 2011. A lexicographical goal programming based decision support system for logistics of Humanitarian Aid. TOP, 19 (2), 464-479.

Pahl, J. \& Voß, S., 2014. Integrating deterioration and lifetime constraints in production and supply chain planning: A survey. European Journal of Operational Research, 238 (3), 654-674.

Panahifar, F., Heavey, C., Byrne, P.J., \& Fazlollahtabar, H., 2015. A framework for Collaborative Planning, Forecasting and Replenishment (CPFR): State of the Art. Journal of Enterprise Information Management, 28 (6), 838-871.

Pazirandeh, A. \& Norrman, A., 2014. An interrelation model of power and purchasing strategies: A study of vaccine purchase for developing countries. Journal of Purchasing and Supply Management, 20 (1), 41 53.

Peppa, V.P. \& Moschuris, S.J., 2013. RFID technology in supply chain management: A review of the literature and prospective adoption to the Greek market. Global Journal of Engineering Education, 15 (1), 61-68.

Pereira, V. \& Costa, H.G., 2015. A literature review on lot size with quantity discounts: 1995-2013. Journal of Modelling in Management, 10 (3), 341-359.

Power, D., 2005. Supply chain management integration and implementation: A literature review. Supply Chain Management: An International Journal, 10 (4), 252-263.

Pyke, D., Robb, D. \& Farley, J., 2000. Manufacturing and Supply Chain Management in China: A Survey of State-, Collective-, and Privately-owned Enterprises. European Management Journal, 18 (6), 577-589. 
Rezapour, S., Farahani, R.Z., Zheng, D. \& Mohammaddust, F., 2014. Strategic design of a competing supply chain network for markets with deterministic demands. IMA Journal of Management Mathematics, DOI: 10.1093/imaman/dpu010.

Rao, S., Goldsby, T.J., 2009. Supply chain risks: a review and typology. International Journal of Logistics Management, 20 (1), 97-123.

Rungtusanatham, M., Choi, T., Y., Hollingworth, D., Wu, Z. \& Forza, C., 2003. Survey research in operations management: historical analyses. Journal of Operations Management, 21 (4), 475-488.

Saad, G., 2006. Exploring the h-index at the author and journal levels using bibliometric data of productive consumer scholars and business-related journals respectively. Scientometrics 69 (1), 117-120.

Sachan, A., Datta, S., 2005. Review of supply chain management and logistics research. International Journal of Physical Distribution \& Logistics Management, 35 (9), 664-705.

Sahin, F., Narayanan, A. \& Robinson, E.P., 2013. Rolling horizon planning in supply chains: Review, implications and directions for future research. International Journal of Production Research, 51 (18), 5413-5436.

Saghiri, S. \& Hill, A., 2014. Supplier relationship impacts on postponement strategies. International Journal of Production Research, 52(7), 2134-2153.

Sarac, A., Absi, N. \& Dauzre-Prs, S., 2010. A literature review on the impact of RFID technologies on supply chain management. International Journal of Production Economics, 128 (1), 77-95.

Sarkis, J., Zhu, Q. \& Lai, K., 2011. An organizational theoretic review of green supply chain management literature. International Journal of Production Economics, 130 (1), 1-15.

Seebacher, G. \& Winkler, H., 2013. A citation analysis of the research on manufacturing and supply chain flexibility. International Journal of Production Research, 51 (1), 3415-3427.

Sel, Ç. \& Bilgen, B., 2015. Quantitative models for supply chain management within dairy industry: A review and discussion. European Journal of Industrial Engineering, 9 (5), 561-594.

Selviaridis, K., Spring, M., 2007. Third party logistics: a literature review and research agenda. International Journal of Logistics Management, 18 (1), 125-150.

Seuring, S., Müller, M., 2008. From a literature review to a conceptual framework for sustainable supply chain management. Journal of Cleaner Production, 16 (15), 1699-1710.

Seuring, S. \& Gold, S., 2012. Conducting content-analysis based literature reviews in supply chain management. Supply Chain Management: An International Journal, 17 (5), 544-555.

Shepherd, C., Günter, H., 2006. Measuring supply chain performance: current research and future directions. International Journal of Productivity and Performance Management, 55 (3/4), 242-258.

Sheppard, A., Tatham, P., Fisher, R. \& Gapp, R., 2013. Humanitarian logistics: enhancing the engagement of local populations. Journal of Humanitarian Logistics and Supply Chain Management, 3 (1), 22-36.

Simangunsong, E., Hendry, L.C. \& Stevenson, M., 2012. Supply-chain uncertainty: A review and theoretical foundation for future research. International Journal of Production Research, 50 (16), 4493-4523.

Simchi-Levi, D., Kaminsky, P. \& Simchi-Levi, E., 2008. Designing and managing the supply chain: concepts, strategies, and case studies, 3rd ed. Boston, MA: McGraw-Hill. 
Smart, P., 2014. The big picture: scholarly publishing trends 2014. Science Editing, 1 (2), 52-57.

Sodhi, M.S., Son, B. \& Tang, C.S., 2012. Researchers' perspectives on supply chain risk management. Production and Operations Management, 21 (1), 1-13.

Srivastava, S.K., 2007. Green supply-chain management: A state-of-the-art literature review. International Journal of Management Reviews, 9 (1), 53-80.

Stadtler, H. \& Kilger, C. eds. 2011. Supply chain management and advanced planning: Concepts, models, software, and case studies, Berlin: Springer-Verlag.

Stevenson, M. \& Spring, M., 2007. Flexibility from a supply chain perspective: Definition and review. International Journal of Operations and Production Management, 27 (7), 685-713.

Stindt, D. and Sahamie, R., 2014. Review of research on closed loop supply chain management in the process industry. Flexible Services and Manufacturing Journal, 26 (1-2), 268-293.

Storey, J., Emberson, C., Godsell, J. \& Harrison, A., 2006. Supply chain management: Theory, practice and future challenges. International Journal of Operations and Production Management, 26 (7), 754-774.

Tang, C.S., 2006. Perspectives in supply chain risk management. International Journal of Production Economics, 103 (2), 451-488.

Tang, O. \& Musa, S.N., 2011. Identifying risk issues and research advancements in supply chain risk management. International Journal of Production Economics, 133 (1), 25-34.

Terzi, S. \& Cavalieri, S., 2004. Simulation in the supply chain context: A survey. Computers in Industry, 53 (1), 3-16.

Tokar, T., 2010. Behavioural research in logistics and supply chain management. The International Journal of Logistics Management, 21, (1), 89-103.

Tyagi, P. \& Agarwal, G., 2014. Supply chain integration and logistics management among BRICS: A literature review. American Journal of Engineering Research, 3 (5), 284-290.

Tyan, J. \& Wee, H.M., 2003. Vendor managed inventory: A survey of the Taiwanese grocery industry. Journal of Purchasing and Supply Management, 9 (1), 11-18.

Upton, D.M. \& Creese, S., 2014. The danger from within. Harvard Business Review, 92 (9), 94-101.

Vaaland, T.I. \& Morten Heide, M., 2007. Can the SME survive the supply chain challenges? Supply Chain Management: An International Journal, 12 (1), 20-31.

van der Vaart, T. \& van Donk, D.-P., 2008. A critical review of survey-based research in supply chain integration. International Journal of Production Economics, 111 (1), 42-55.

van Weele, A.J., 2010. Purchasing and Supply Chain Management: Analysis, Strategy, Planning and Practice, 5th ed. Hampshire, UK: Cengage Learning Business Press.

Vidai, C.J. \& Goetschalckx, M., 1997. Strategic production-distribution models: A critical review with emphasis on global supply chain models. European Journal of Operational Research, 98 (1), 1-18.

Walker, W.T., 2005. Emerging trends in supply chain architecture. International Journal of Production Research, 43 (16), 3517-3528.

Wang, W. \& Fu, W.P., 2010. Review of research on modeling and simulation for dynamics and complexity of supply chain systems. Journal of System Simulation, 22 (2), 271-279. 
Williams, Z., Lueg, J.E. \& LeMay, S.A., 2008. Supply chain security: an overview and research agenda. The International Journal of Logistics Management, 19 (2), 254-281.

Wong, W.P. \& Wong, K.Y., 2008. A review on benchmarking of supply chain performance measures. Benchmarking, 15 (1), 25-51.

Yang, B. \& Yang, Y., 2010. Postponement in supply chain risk management: a complexity perspective. International Journal of Production Research, 48 (7), 1901-1912.

Zeng, Y., Wang, L., Deng, X., Cao, X. \& Khundker, N., 2012. Secure collaboration in global design and supply chain environment: Problem analysis and literature review. Computers in Industry, 63 (6), 545556.

Zhonghua, Y. \& Ling, Zh., 2013. Information sharing in supply chain: a review. Journal of Digital Information Management, 11 (2), 125.

Zou, P.X.W. \& Seo, Y., 2006. Effective applications of e-commerce technologies in construction supply chain: Current practice and future improvement. Electronic Journal of Information Technology in Construction, 11, 127-147. 